\title{
PESQUISA DE BACTÉRIAS, FUNGOS, PROTOZOÁRIOS E CRISTAIS EM BILE VESICULAR*
}

\author{
Mauro Siqueira**, Diva Montenegro** e William Stanford***
}

\begin{abstract}
Os autores estudaram 40 vesiculas $e$ bile de cadáveres $e 23$ de portadores de colecistopatia que se submeteram à cirurgia; procuraram averiguar o percentual de positividade para bactérias, fungos, cristais e cálculos, para uma possivel avaliação de etioloqia das colecistopatias. Encontraram um elevado percentual de cristais - $60 \%$ em cadáveres e $63 \%$ em vesiculas cirúrgicas -, $e$ um baixo indice de fungos - $2,5 \%$ em cadáveres e $0 \%$ em bile vesicular cirürgica. Dos 23 casos cirürgicos, encontraram $13 \%$ de biles infectadas por bactérias e $50 \%$ em cadáveres que nunca referiram, em vida, qualquer sintoma que fizesse suspeitar colecistopatia.
\end{abstract}

\section{INTRODUÇĂO}

A bibliografia médica é por demais vasta no estudo das tubagens duodenais, onde procuraram alguns autores estudar as colecistopatias através das tubagens e estimulo com substâncias as mais variadas, sendo comumente usado o sulfato de magnésio e o óleo de oliva.

Outros autores se propōem a tratar os problemas funcionais da vesícula biliar através de estímulos introduzidos diretamente no duodeno.

Em 1959, Batista e cols. (1) referem o isolamento de fungos leveduriformes em um elevado percentual de $65,5 \%$ dos pacientes, e acreditam que a formação de cálculos pode ser motivada por colecistites micóticas, embora afirmem que, até o momento de seu trabalho, seja ignorada a patogenicidade dos fungos na árvore biliar. O mesmo autor refere que Negrone cita quatro casos de fungos isolados da bile humana.
Spellberg (4) diz que a colelitíase e a obstrução precedem a inflamação aguda. Diz, ainda, que nas primeiras 24 horas após o desenvolvimento do quadro clínico da colecistite aguda, $65 \%$ dos cálculos são estéreis, e a incidência de culturas positivas atingiu a $80 \%$ após o 3 \% dia da doença.

Girardi (2) em um caso de colecistite encontrou, junto ao muco proveniente das vias biliares, um hifomiceto e supôs que o mesmo estava sediado na vesícula biliar. Após a colecistectomia foram encontrados numerosos cálculos, resultando negativa a procura do referido hifomiceto na bile e nas paredes da vesícula. Chegou à conclusão, portanto, de que o mesmo havia sido proveniente da cavidade gástrica e eliminado pelo fluxo biliar.

Russo (3), estudando vinte e uma vesículas cirúrgicas, encontrou duas amostras de Escherichia coli (não patogênica), um $E$. coli tipo Sorológico 0111: $\mathbf{B}_{4}$, duas Shigella flexneri e uma Shigella alkalecens

* Trabalho realizado no Instituto de Medicina Tropical da Faculdade de Medicina da Universidade Federal de Pernambuco.

* * Professôres-assistentes do Instituto de Medicina Tropical da F.M.U.F.Pe.

** * Endocopista e cirurgiăo do Instituto de Medicina Tropical da F.M.U.F.Pe.

Recebido para publicaçăo em 25-2-71. 
RESULTADOS OBTIDOS

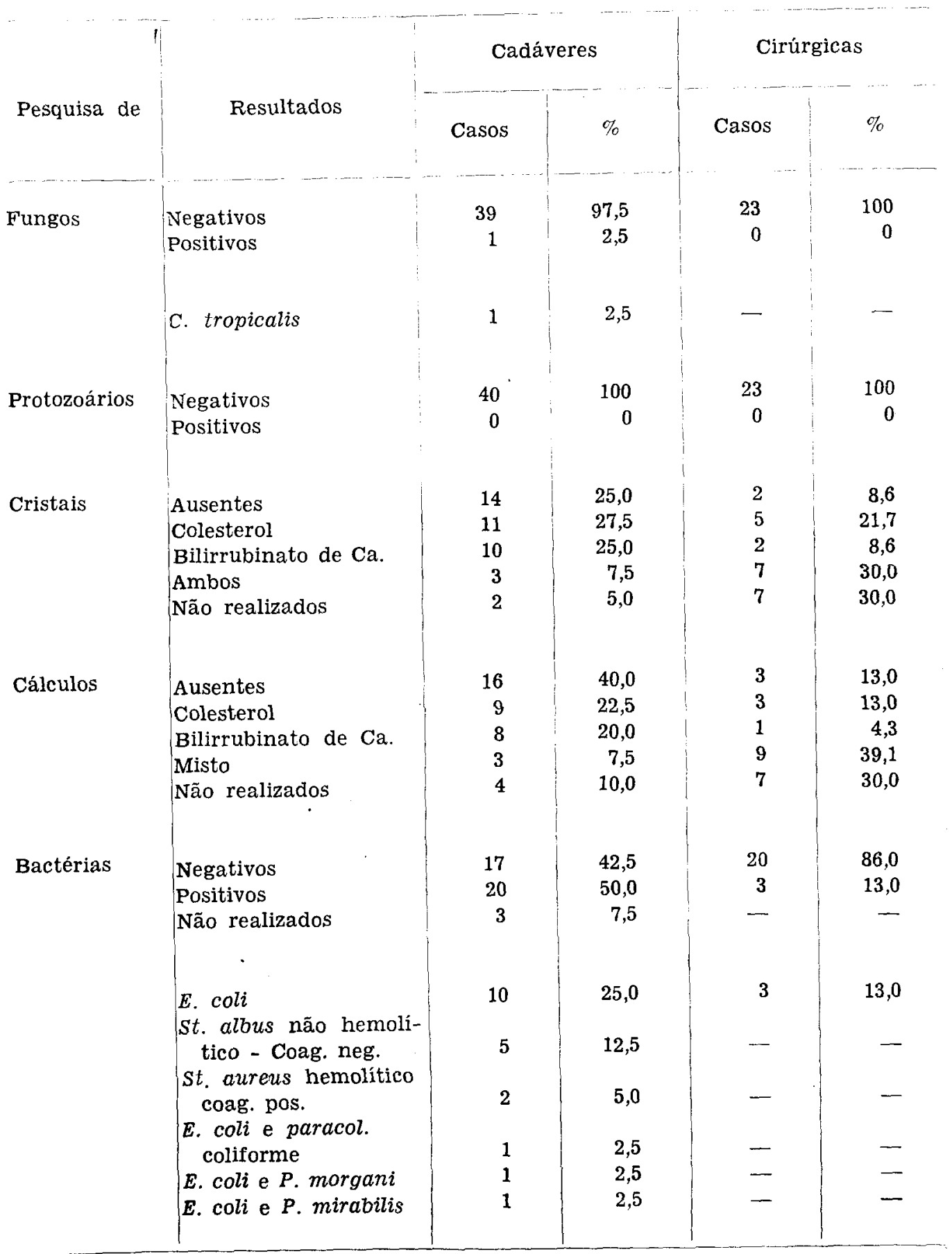


e, em um caso, Giardia lamblia, obtendo, assim, um total de $23 \%$ de vesículas infectadas.

Êste autor não refere o achado, em exame direto nem através de cultivos em caldo peptonado, de qualquer estrutura fủngica.

Além destas teorias orgânicas, merece referência a teoria psicógena que procura justificar as calculoses baseada na inibição da contração vesicular e das aberturas dos enfincteres (cístico e de Oddi) por alterações psíquicas.

\section{MATERIAL E MÉTODOS}

Com o intuito de observar a etiologia das colecistopatias, elaboramos um esquema de pesquisa que dividimos em duas partes. A primeira consta da retirada das vesículas de 40 cadáveres; estas vesículas foram submetidas à necropsia em menos de 20 horas do falecimento; não havia queixas nem qualquer exame sugestivo de colecistopatia nos casos considerados. As vesículas eram ligadas antes da exerese e enviadas ao laboratório, onde, após assepsia local com mertiolate e esterilização com uma lâmina ao rubro, puncionávamos o local com agulha estéril e semeávamos o líquido aspirado nos meios de Sabouraud com ledermicina para pesquisa de fungos, e para bactérias, nos meios de agar sangue, Teague e caldo Tetrationato. Além disso, fazíamos um exame microscópico direto à procura de protozoários e para estudo dos cristais existentes. Nesta ocasião, retirávamos ainda um fragmento da parede vesicular, encaminhando-o para estudo histopatológico.

Na segunda parte planejamos a mesma técnica anteriormente descrita, sendo o material colhido de 23 pacientes com sintomas de colecistopatias e que se submeteram à colecistectomia. Resumimos nossos achados no quadro anexo.

\section{COMENTÁRIOS}

No que concerne à presença de protozoários e fungos, deixamos de tecer comentários em vista da ausência de dados estatísticos que permitissem avaliar a presença dêstes elementos originando as calculoses vesiculares. Podemos, porém, comparar os nossos resultados com os obtidos por Russo em 1957 (3), que também não refere o achado de fungos e apenas encontrou um caso de Giardia lamblia localizada na vesícula biliar e Batista e cols. em 1959 (1), que obteve uma positividade para fungos $(65,5 \%)$ bem superior à nossa, em que apenas isolamos, em uma vesícula de cadáver, Candida tropicalis.

Nossos achados, com $13 \%$ de positividade para Escherichia coli (não patógena) em vesículas cirúrgicas, se superpõem aos de Russo (3), embora para as demais espécies não tenhamos obtido positividade.

Em cadáveres houve uma maior incidência de bactérias na vesícula, o que já era de se esperar, em vista das ótimas condições que oferece a bile $\mathrm{em}$ estase para o desenvolvimento de microorganismos.

Nosso estudo histopatológico não permitiu conclusões em vista do grande número de material autolizado, embora tivéssemos colocado os fragmentos em formalina, logo após a retirada; nos casos em que foi possível o estudo, foram encontrados apenas sinais de inflamação inespecífica ( 3 casos), os demais estando dentro dos limites da normalidade.

O resultado da pesquisa de cristais assemelha-se ao de Russo (3), predominando os cristais mistos e de colesterol sôbre o de bilirrubinato de cálcio. Os cálculos também em sua maioria eram mistos e de colesterol.

\section{CONCLUSÕES}

a) pouco estudada, do ponto-de-vista bacteriológico e micológico, a bile vesicular.

b) rara a presença de fungos na bile vesicular.

c) O achado de cristais na bile vesicular representa um percentual considerável $(60,3 \%)$.

d) Predomina a freqüência de cálculos mistos sôbre os demais.

e) Em bile vesicular de cadáveres a freqüência de bactérias é de $50 \%$.

f) $\mathrm{Em} \mathbf{5 0} \%$ das vesículas de cadáveres estudadas foram encontrados cálculos e em $60 \%$ foram identificados cristais. 


\section{S U M M A R Y}

The authors present the results of the research on the bile from gallbladders of 40 cadavers and 23 additional gall-bladers removed by surgery.

They examined the presence of fungi and bacteria as well as bile stones and crystals. was found.

A high incidente of bile crystals - $60 \%$ in gallbladders from cadavers

A low incidence of fungi was found - 2,5\% in bile of gallbladders from cadavers and none in bile of surgically removed gallbladders.

Bacteria was present in bile in $13 \%$ of surgically removed gallbladders and in $50 \%$ gallbladders from cadavers.

There was a marked high incidence of gallstones in cadavers.

\section{B I B L I O G R A F I A}

1. BATISTA, A.C.; OLIVEIRA, S.D. \& SILVEIRA, G.L. - Colecistites Micóticas - Proceedings of the Sixt Internacional Congress in Tropical Medicine and Malária. Vol. IV, pgs. 754-761, Lisboa, september 5-13, 1958.

2. GIRARDI, P. - A entubação duodenal no diagnóstico e na terapêutica. Vol. VIII. 1 - 181 - Fig. 15, Compên- dio Nacional Edit., Rio de Janeiro, 1940.

3. RUSSO, E. - Exame bacteriológico de 21 vesículas calculosas após colecistectomia. O Hospital, vol. 67, no 3, 1965.

4. SPELLBERG, M.A. - Diseases of liver. Grune e Sratton Edit., New York 1954. 